\title{
Peran Auditor Dalam Menurunkan Biaya Utang Sebelum Dan Setelah Go Public
}

\author{
Sansaloni Butar Butar \\ Universitas Katolik Soegijapranata \\ sansaloni@unika.ac.id \\ Stefani Lily Indarto \\ Universitas Katolik Soegijapranata \\ sli@unika.ac.id \\ Sih Mirmaning Damar Endah \\ Universitas Katolik Soegijapranata \\ sihmirmaning@unika.ac.id
}

\begin{abstract}
his study examine the role of auditors and firm's reputation in lowering firm's cost of debt before and after Initial Public Offering. Firms gradually build reputation and history in the capital markets and thus information of older firms are widely available and increasing with age. Firms with highly regarded reputation are predicted to pay lower interest rate relative to those with lower reputation. To test the hypothesis, as much as 161 sampel firms are collected from Indonesia Stock Exhange over period 2003-2012. Results show, contrary to the prediction, that auditor reputation has no association with cost of debt. However, negative association between auditor reputation and cost of debt was found for firms with short private history. In additon, the results also provide no evident of the interaction between auditor reputation and age. Taking as a whole, the findings in this study shows that the role of auditors in reducing cost of debt were effective only before firms went public.
\end{abstract}

Keywords: Auditor reputation, cost of debt, firm reputation, IPO, firm age.

\begin{abstract}
Abstrak
Studi ini menguji peran auditor dan reputasi perusahaan dalam menurunkan biaya hutang perusahaan sebelum dan sesudah go public. Perusahaan membangun reputasi dan sejarah di pasar modal secara bertahap sehingga informasi mengenai perusahaan yang telah lama beroperasi tersedia secara luas. Penelitian ini berargumen bahwa perusahaan dengan reputasi yang baik membayar suku bunga yang lebih rendah dibandingkan. Untuk menguji hipotesis, sebanyak 161 sampel perusahaan dikumpulkan dari Bursa Efek Indonesia selama periode 2003-2012. Hasil analisis regresi menunjukkan bahwa reputasi auditor tidak berpengaruh pada biaya hutang. Selain itu, hasilnya juga tidak memberikan bukti interaksi antara reputasi dan usia auditor. Namun, hubungan negatif antara reputasi auditor dan biaya hutang ditemukan untuk perusahaan dengan sejarah pribadi yang pendek. Secara keseluruhan, temuan dalam penelitian ini menunjukkan bahwa peran auditor dalam mengurangi biaya hutang hanya efektif sebelum perusahaan go public.
\end{abstract}

Kata Kunci: Reputasi auditor, biaya hutang, reputasi perusahaan, IPO, umur perusahaan 


\section{PENDAHULUAN}

Penjelasan teoretis tentang hubungan antara pertumbuhan ekonomi dan pertumbuhan sektor keuangan di suatu negara telah banyak dikemukakan oleh para ahli ekonomi. Argumen konseptual yang dikembangkan umumnya menekankan peran sektor keuangan dalam mendorong peluang-peluang investasi, mobilisasi tabungan dan dalam meningkatkan inovasi teknologi (Rajan dan Singales, 1998). Studi empiris yang dilakukan Levine dan Zervos (1998) menemukan hubungan positif antara pertumbuhan ekonomi dan perkembangan sektor keuangan di suatu negara. Sementara Rajan dan Singales (1998) melaporkan negara-negara yang memiliki pasar keuangan yang lebih maju mengalami pertumbuhan industri yang cepat.

Lebih jauh Rajan dan Singales (1998) mengidentifikasi adanya siklus tertentu dalam pola pendanaan perusahaan. Pada masa-masa awal berdiri, perusahaan sangat bergantung pada pendanaan eksternal. Pada fase berikutnya, pendanaan eksternal melalui IPO menjadi sumber pendanaan utama hingga tahun yang ke sepuluh. Setelah perioda tersebut, ekuitas bersih yang diterbitkan perusahaan dan pemakaian dana eksternal berfluktuasi mendekati nol. Analisis lanjutan menunjukkan bahwa pasar kredit mengalami friksi akibat kesenjangan informasi (information asimetry). Akibat friksi tersebut alokasi kredit kepada perusahaan menjadi terganggu dan tidak tepat sasaran.

Peluang terjadinya kesalahan dalam pengalokasian kredit semakin besar pada perusahaan-perusahaan yang baru berdiri karena informasi tentang perusahaan belum banyak dipublikasikan di pasar. Ketersediaan informasi tentang perusahaan menjadi faktor penting bagi perbankan dalam mengevaluasi kelayakan kredit. Chan et al., (2013) memberi bukti hubungan positif antara asimetri informasi dengan biaya utang. Salah satu informasi penting yang digunakan bank dalam mengevaluasi kelayakan kredit yaitu laporan keuangan. Laporan keuangan yang lebih konservatif dipercaya memiliki kualitas yang tinggi. Menggunakan data dari pasar modal China, Chen dan Zhu (2015) menemukan biaya utang (cost of debt) jangka panjang memiliki hubungan negatif dengan akuntansi konservatif. Hasil yang konsisten juga ditemukan Chan et al., (2013) dengan menggunakan data dari pasar modal Taiwan dan Vander et al., (2015) yang menggunakan kualitas akrual sebagai proksi kualitas laporan keuangan. Namun, kepercayaan bank atas keandalan laporan keuangan perusahaanperusahaan yang baru berdiri diekspektasi lebih rendah dibandingkan dengan perusahaan yang sudah lama berdiri. Kepercayaan yang rendah dapat mempengaruhi tingkat bunga yang dibebankan pada perusahaan.

Bagi perusahaan yang belum memiliki rekam jejak yang panjang, satu cara untuk meningkatkan kepercayaan pihak luar atas keandalan laporan keuangan adalah dengan menyewa auditor yang memiliki reputasi yang tinggi (Diamond, 1989; Datar et al., 1999; Copley dan Dauthett, 2002). Keputusan perusahaan memilih auditor yang telah memiliki reputasi yang baik merupakan sinyal penting bagi pelaku pasar untuk menilai keandalan angka-angka yang tersaji dalam laporan keuangan. Auditor yang memiliki reputasi baik dipandang mampu memberikan jasa audit berkualitas yang dapat meminimalkan salah saji material dan meningkatkan kualitas pengambilan keputusan.Dengan memilih auditor yang bereputasi tinggi perusahaan memberi sinyal kepada pengguna laporan keuangan bahwa perusahaan telah melaporkan setiap peristiwa ekonomi yang terjadi sesuai dengan fakta. Bagi kreditur, pemilihan auditor yang bereputasi tinggi memberi keyakinan tentang keandalan angka-angka yang tersaji, meningkatkan keyakinan tentang kemampuan perusahaan mengembalikan pinjaman, dan menjadi bahan pertimbangan dalam menurunkan tingkat bunga yang dibebankan.

Mansi et al., (2004), menguji pengaruh kualitas auditor dan tingkat pengembalian (yield) obligasi. Mereka menemukan kualitas auditor dan yield berhubungan negatif. Pittman dan Fortin (2004) menemukan tingkat bunga perusahaan yang diaudit oleh auditor Big Six 
lebih rendah daripad non-Big Six. Sementara Fortin and Pittman (2007) yang menggunakan sampel perusahaan privat gagal menemukan hubungan antara kualitas auditor dan yield spread. Kim et al., (2011) menguji hubungan loan spread dan kualitas auditor dan menemukan adanya perbedaan loan spread yang dibebankan bank pada perusahaan yang diaudit oleh kantor akuntan Big Fourdan non-Big Four. Sebagai tambahan, Kim et al., (2011) juga menguji tingkat bunga yang dibebankan pada perusahaan privat. Hasil penelitian memperlihatkan bukti bahwa tingkat bunga yang dibebankan pada perusahaan privat yang telah diaudit lebih rendah dibanding yang tidak diaudit.

Hasil-hasil penelitian terdahulu menunjukkan hubungan antara kualitas auditor dan biaya utang tidak konsisten. Oleh karena itu, penelitian ini bertujuan untuk memberi bukti tambahan pengaruh kualitas auditor terhadap biaya utang perusahaan-perusahaan yang baru mencatatkan saham (go public) di Bursa Efek Indonesia dalam menurunkan biaya utang. Lebih spesifik, penelitian ini menguji peran auditor dan umur perusahaan setelah IPO. Sebagai tambahan, penelitian ini juga menguji dampak auditor terhadap tingkat bunga pada perusahaan yang memiliki sejarah privat yang pendek dan panjang (sebelum IPO).

\section{TINJAUAN LITERATUR DAN PERUMUSAN HIPOTESIS}

\section{Kualitas Audit dan Ukuran KAP}

Diamond (1989) menyatakan bahwa kesenjangan informasi yang terjadi di pasar keuangan antara perusahaan dan penyedia modal lebih tinggi pada perusahaanyang belum memiliki umur yang panjang.Ketersediaan informasi yang minim menyulitkan pasar untuk menilai kemampuan perusahaan dalam memberikan return yang memuaskan.Minimnya informasi tentang perusahaan berkaitan dengan reputasi perusahaan di masa lalu yang berdampak pada persepi pasar tentang keandalan laporan keuangan perusahaan dan selanjutnya meningkatkan risiko ketidaktertagihan.Karena itu, perusahaaan perlu mencari cara untuk menyakinkan bank bahwa mereka layak untuk mendapatkan pinjaman. Salah satu cara yang dapat ditempuh adalah dengan menyewa auditor yang memiliki reputasi yang tinggi (Datar et al., 1991).

Datar et al.(1991) mengembangkan model yang menjelaskan pentingnya laporan yang telah diaudit.Mereka berargumen bahwa laporan keuangan yang telah diaudit bermanfaat bagi pemilik perusahaan yang memiliki informasi privat dan yang sedang mencari investor untuk menanggung bersama-sama risiko perusahaan.Dalam model tersebut mereka mengasumsikan auditor yang dipilih dan laporan audit yang dihasilkan hanya memberikan setengah informasi tentang informasi privat yang dimiliki pemilik, dan pemilik memilih untuk menahan sebagian saham perusahaan sebagai sinyal tambahan untuk menghilangkan sebagian lagi ketidakpastian yand dihadapi investor.Copley dan Dauthett (2002) menguji model yang dikembangkan Datar et al. (1991) dan menemukan bahwa pilihan auditor (auditor choice) dan pengungkapan langsung menjadi sinyal pengganti atas kepemilikan saham yang ditahan.Lebih jauh lagi mereka menunjukkan bahwa sinyal yang dipilih (diantaranya, kepemilikan yang ditahan, auditor yang dipilih dan pengungkapan) saling berhubungan melalui struktur biaya dan secara bersama-sama memperkecil keseluruhan biaya yang harus ditanggung pemilik.

Dalam literatur akuntansi, kualitas audit dapat dipandang dalam berbagai perspektif. Namun, definisi tentang kualitas audit yang digunakan selama ini pada umumnyamenggunakan definisi yang dikembangkan dalam DeAngelo (1981). Menurut DeAngelo, audit yang berkualitas adalah apabila seorang auditor mampu mendeteksi pelanggaran dalam proses pelaporan keuangan dan melaporkan pelanggaran tersebut. Lebih jauh lagi dikatakan bahwa ukuran kantor akuntan merefleksikan kualitas jasa audit yang 
diberikan. Sementara, Palmrose (1988) mempersingkat definisi kualitas audit sebagai probabilitas bahwa laporan keuangan tidak mengandung salah saji material.

Ukuran kantor akuntan merupakan salah satu proksi kualitas audit yang selalu digunakan dalam riset empiris selama ini. DeAngelo (1981) menuturkan bahwa konsekuensi hukum yang harus ditanggung oleh kantor akuntan berukuran besar lebih tinggi daripada kantor akuntan kecil. Hal ini tidak terlepas dari besarnya pendapatan yang mereka terima dari jasa audit yang diberikan. Pendapatan yang relatif besar dibandingkan kantor akuntan kecil menyebabkan posisi kantor akuntan besar lebih berisiko ketika menghadapi tuntutan hukum. Pihak-pihak yang mengalami kerugian besar akibat laporan keuangan yang tidak wajar berupaya mendapatkan uang pengganti dengan menuduh auditor telah melakukan kesalahan pengauditan.Kompensasi yang harus dibayar lebih besar dibanding kantor akuntan kecil karena pihak yang dirugikan memandang kantor akuntan besar memiliki kekayaan besar. Risiko tuntutan hukum yang tinggi mendorong kantor akuntan besar meningkatkan kualitas jasa audit yang mereka berikan. Pendapat yang sama dikemukakan Dye (1993) yang menyatakan bahwa investasi besar yang dikeluarkan untuk meningkatkan kemampuan auditor dan membangun reputasi serta didukung dengan kemampuan keuangan yang besar (deep pockets) menjadi alasan kuat bagi kantor akuntan untuk menghindari risiko tuntutan hukum. Sementara Boone et al. (2010) menyatakan kantor akuntan besar diekpektasi menawarkan kualitas jasa audit yang lebih tinggi dibanding kantor akuntan kecil karena penghasilan kantor akuntan besar tidak bergantung pada satu klien tertentu. Kondisi seperti ini dapat meningkatkan independensi kantor akuntan dan dengan sendirinya meningkatkan kualitas audit. Sebagai tambahan, kantor akuntan besar memiliki dana besar untuk berinvestasi pada teknologi audit.

Riset terdahulu yang menguji dampak pemakaian kantor akuntan besar yang memiliki reputasi internasional menemukan bukti adanya peningkatan kualitas laporan keuangan dan kepercayaan pasar. Becker et al. (1998) menunjukkan bahwa manajemen laba laporan keuangan yang diaudit kantor akuntan yang memiliki nama besar lebih rendah dibandingkan dengan perusahaan yang diaudit kantor akuntan yang tidak memiliki nama besar. Beatty (1989) menemukan pasar merespon positif laporan keuangan yang diaudit oleh kantor akuntan yang memiliki reputasi internasional.

\section{Biaya Utang}

Pada umumnya struktur modal perusahaan merupakan bauran antara utang dan ekuitas.Penelitian empiris tentang dampak kualitas audit terhadap biaya ekuitas mendominasi literatu akuntansi dan keuangan, hanya sedikit yang membahas dampaknya terhadap biaya utang. Beberapa penelitian seperti Beatty (1989) dan Pittman dan Fortin (2004) menguji dampak kualitas audit terhadap biaya utang menggunakan konteks biaya ekuitas. Dalam pembahasan tentang pengaruh kualitas audit terhadap biaya utang, peneliti mengikuti studistudi terdahulu yang menggunakan konteks pengaruh kualitas audit terhadap biaya ekuitas. Namun harus dicatat bahwa masalah keagenan yang terjadi antara manajer dan pemegang utang bisa saja berbeda dengan pemegang saham. Karena itu, dampak kualitas audit terhadap biaya utang mungkin berbeda dengan dampaknya terhadap biaya ekuitas.

Untuk menilai pengaruh kualitas audit terhadap biaya utang, riset-riset terdahulu umumnya menggunakan argumen konseptual yang menghubungkan kualitas audit dan biaya ekuitas, khususnya pada saat perusahaan melakukan IPO.Kondisi pasar pada saat IPO memiliki karakteristik yang unik dimana kesenjangan informasi mengenai nilai perusahaan antara perusahaan dan investor sangat tinggi.Agar saham yang dijual tidak dinilai terlalu rendah (under value) oleh pasar, perusahaan berupaya menyampaikan informasi privat yang dimiliki melalui mekanisma pensinyalan, salah satunya adalah dengan memilih auditor yang berkualitas (Datar et al., 1991; Beatty., 1989).Kesenjangan informasi juga terjadi di pasar 
utang.Keputusan perusahaan untuk memilih auditor Big $\mathrm{N}$ dilandasi oleh keinginan untuk meningkatkan kredibilitas laporan keuangan perusahaan di mata kreditor dan pada gilirannya menurunkan biaya kontrakting.

Ketika mengajukan permintaan kredit ke bank atau lembaga pinjaman lainnya, perusahaan diwajibkanuntuk menyampaikan proposal yang berisi rencana-rencana perusahaan di masa mendatang yang dilengkapi dengan laporan keuangan yang telah diaudit. Informasi ini memungkinkan investor untuk memahami kondisi kesehatan keuangan saat ini dan prospek perusahaan ke depan dalam rangka menetapkan besaran tingkat bunga yang akan dibebankan sesuai penilaian tentang default risk.Semakin tinggi probabilitas kegagalan perusahaan untuk mengembalikan utang, maka semakin tinggi pula tingkat bunga yang dibebankan. Literatur perbankan mengindikasikan default risk merupakan salah satu penentu beban utang yang harus ditanggung perusahaan (misalnya, Freixas dan Rochet, 1997). Studi yang dilakukan Kim et al. (2011) memperlihatkan bahwa loan spread yang dibebankan bank pada perusahaan yang diaudit kantor akuntan Big Four lebih rendah daripada non-Big Four.Lebih jauh Kim et al. (2011) menunjukkan bahwa tingkat bunga yang dibebankan pada perusahaan yang laporan keuangannya telah diaudit lebih rendah dibanding yang tidak diaudit.

\section{Pengaruh Reputasi Terhadap Tingkat Utang}

Hasil-hasil studi terdahulu menunjukkan bahwa kualitas laporan keuangan yang diaudit oleh auditor Big N (big 8/6/5/4) lebih tinggi daripada kualitas laporan keuangan yang tidak di audit oleh Big N. Francis et al. (1999) menemukan bahwa auditor Big N meningkatkan kualitas laba karena menurunkan kecenderungan perusahaan melaporkan laba secara agresif dan menurunkan kecenderungan melakukan manajemen laba. Becker et al. (1998) memberikan bukti bahwa laba perusahaan yang menggunakan auditor Big $\mathrm{N}$ mengandung akrual diskresioner yang lebih rendah.Sementara, Teoh dan Wong (1993) melaporkan bahwa perusahaan yang diaudit oleh Big $\mathrm{N}$ memiliki earnings response coefficients yang lebih tinggi.Temuan-temuan empiris di atas mengindikasikan bahwa kualitas laba yang disajikan oleh perusahaan yang diaudit Big $\mathrm{N}$ lebih tinggi dibanding dengan perusahaan yang tidak diaudit oleh Big N.

Temuan-temuan di atasjuga mengindikasikan bahwa kualitas audit tinggi yang diberikan oleh auditor Big $\mathrm{N}$ menurunkan tingka manajemen laba yang sering digunakan untuk memenuhi kontrak utang melalui perubahan kebijakan akuntansi (Sweeney, 1994) dan akrual diskresioner (DeFond dan Jiambalvo, 1991). Sementara Dhaliwal et al. (2008) menemukan biaya utang perushaan-perusahaan yang menggunakan jasa kantor akuntan yang bereputasi menurun seiring dengan meningkatnya fee audit.

Kesenjangan informasi dapat menghalangi pengalokasiandana secara produktif dan efisien. Pittman dan Fortin (2004) menyatakan bahwa masalah kesenjangan informasi akan berkurang dengan bertambahnya umur perusahaan karena pertambahan umur meningkatkan akumulasi informasi tentang perusahaan di pasar dan semakin banyak pelaku pasar mengetahuinya. Studi yang menguji reaksi pasar terhadap pengumuman laba oleh Lang (1991) memperlihatkan bahwa magnituda reaksi pasar menurun seiring dengan bertambahnya umur perusahaan. Dia berpendapat bahwa menurunnya reaksi pasar disebabkan makin banyaknya informasi tentang perusahaan yang dapat diakses oleh pelaku pasar dengan berlalunya waktu.Studi Lang mengindikasikan bahwa reputasi yang dibangun oleh perusahaan penting untuk meningkatkan kepercayaan pasar.

Peran reputasi dalam mengurangi konflik kepentingan antara debitur dan kreditur menjadi fokus analisis Diamond (1989). Dalam model yang dikembangkan, dia memperlihatkan bahwa masalahinsentif antara peminjam dan pemberi pinjaman lebih besar dihadapi oleh dibitur yang memiliki rekam jejak (track record) yang pendek dan 
masalahinsentif tersebut semaking berkurang seiring dengan meningkatnya reputasiperusahaan. Lebih jauh, dia berargumen bahwa jika adverse selection terjadi secara masif, tingkat bunga yang dibebankan kepada debitur akansemakin tinggi. Nilai sekarang (present value)dari serangkaian rente di masa depan yang diperoleh perusahaan yang belum memiliki reputasi baik diekspektasi lebih rendah dibandingkan perusahaan yang telah memiliki reputasi. Rente yang rendah akibat dari keterpaksaan perusahaan memilih proyek jangka pendek yang berisiko tinggi dan bernilai rendah. Namun, perusahaan yang mampu menangani proyek berisiko dan mampu membayar pinjamannnya secara kontinu perlahanlahanakan menaikkan nama baik perusahaan. Selanjutnya, reputasi yang baik akan membantu menurunkan tingkat bunga serta meningkatkan present value dari serangkaian rente yang diterima di masa depan. Pada akhirnya, rente tinggi yang diterima perusahaan memampukan perusahaan memilih proyek aman yang bernilai tinggi.

Argumen Lang (1991) dan Diamond (1989) di atas mengisyaratkan bahwa perusahaan harus menunggu lama sebelum mendapatkan kepercayaan penyandang dana. Hal ini dapat merugikan perusahaan yang memiliki kinerja yang baik tetapi belum memiliki rekam jejak yang panjang.Dalam kondisi seperti ini, Datar et al. (1991) menganjurkan perusahaan memberikan sinyal yang kredibel ke pasar untuk memberitahu publik prospek perusahaan sesungguhnya. Dalam studi tersebut, salah satu mekanisma pensinyalan yang dapat dilakukan adalah dengan menggunakan jasa auditor.Mereka menguji peran auditor dalam memberikan sinyal informasi privat yang dimiliki perusahaan dan memberikan bukti bahwa kualitas auditor memiliki kandungan informasi.Lebih jauh lagi, hasil analisis menunjukkan bahwa tuntutan terhadap audit yang berkualitas meningkat seiring dengan meningkatnya risiko spesifik perusahaan.Secara keseluruhan, hasil-hasil analisis yang dikemukakan dalam Datar et al. (1991) mengindikasikan bahwa tingkat bunga diekspektasi menurun seiring dengan meningkatnya kepercayaan (reputasi) dan perusahaan-perusahaan yang belum memiliki rekam jejak yang panjang (baru berdiri) disarankan untuk menyewa auditor yang berkualitas tinggi.

Pittman dan Fortin (2004) menyatakan auditor yang memiliki reputasi tinggi dapat membantu menyelesaikan masalah kontrak (contracting problem) karena memberikan informasi yang berharga tentang perusahaan kepada pemilik modal. Lebih jauh lagi dikatakan, keterbatasan informasi yang tersedia tentang perusahaan-perusahaan muda (young firms), memaksa pemberi pinjaman bergantung penuh atas informasi-informasi yang diungkapkan perusahaan untuk mengevaluasi kinerja dan prospek di masa depan. Sulitnya untuk menilai kredibilitas laporan keuangan perusahaan-perusahaan muda tersebut, mendorong pemberi pinjaman mengeluarkan biaya pemrosesan informasi yang besar dengan menggunakan sumber alternatif.Selanjutnya mereka mengatakan kredibilitas laporan keuangan dapat ditingkatkan dengan menggunakan auditor yang memiliki reputasi tinggi seperti auditor Big 6.

Pitman dan Fortin (2004) menguji hubungan biaya utang dengan reputasi auditor menggunakan sampel perusahaaan yang terdaftar di pasar modal Amerika. Mereka menemukan biaya utang perusahaan yang diaudit kantor akuntan Big Six lebih rendah dibandingkan perusahaan yang menggunakan kantor akuntan biasa. Lebih jauh mereka menemukan efek penurunan semakin berkurang seiring bertambahnya usia perusahaan. Berkurangnya ketidakpastian tentang kualitas laba perusahaan menjadi dorongan bagi pemberi pinjaman untuk mempertimbangkan auditor yang dipilih perusahaan sebagai dasar dalam memberi pinjaman.Perusahaan-perusahaan muda akan mendapat manfaat yang lebih dengan menyewa auditor Big $\mathrm{N}$ karena ketidakpastian tentang kualitas laba yang dilaporkan perusahaan menurun seiring dengan bertambahnya umur perusahaan.

Karjalainen (2011) menguji relevansi nilai kualitas audit dan opini audit terhadap biaya utang perusahaan-perusahaan privat di Finlandia. Hasil penelitian menunjukkan perusahaan 
yang diaudit kantor akuntan Big 4 memiliki biaya utang yang lebih rendah. Selain itu, hasil penelitian juga menunjukkan perusahaan yang memiliki opini audit modifikasian dibebankan biaya utang yang lebih tinggi. Analisis tambahan menemukan kualitas audit persepsian lebih penting bagi perusahaan besar.

Sementara, pemberi pinjaman yang tidak yakin tentang angka-angka yang tercermin dari laporan keuangan akanterdorong untuk membebankan bunga yang lebih tinggi untuk memproteksi dari risiko ketidaktertagihan. Peran auditor dalam menurunkan biaya utang diekspektasi berjalan efektif hanya pada perusahaan yang belum memiliki rekam jejak yang panjang. Dengan berjalannya waktu pemberi pinjaman lebih mengandalkan reputasi perusahaan daripada auditor dalam menentukan tingkat bunga yang akan diberikan.

Karena itu, pengaruh yang ditimbulkan dengan memilih auditor Big $\mathrm{N}$ terhadap biaya utang lebih dapat terdeteksi pada perusahaan-perusahaan muda yang belum memiliki rekam jejak yang menyakinkan. Hubungan antara umur perusahaan dan biaya utang dapat dinyatakan dalam hipotesis berikut ini:

\section{H1 A: Biaya utang menurun seiring bertambahnya umur perusahaan \\ H1в: Biaya utang perusahaan yang menggunakan auditor Big Four lebih rendah daripada yang tidak menggunakan Big Four. \\ H1c: Pengaruh auditor Big Four dalam menurunkan biaya utang berkurang dengan bertambahnya umur perusahaan.}

\section{Rekam Jejak Perusahaan dan Umur Perusahaan}

Pada suatu saat dalam tahapan pertumbuhannya, perusahaan harus memutuskan apakah tetap menjadi perusahaan privat atau berubah menjadi perusahaan publik. Chemmanur dan Fulghieri (1999) mengembangkan model untuk menentukan saat yang tepat bagi perusahaan menjual saham ke publik. Dalam model tersebut, mereka melakukan analisis tentang keuntungan dan kerugian jika pendanaan diperoleh dari kelompok investor yang luas melalui penjualan saham ke publik atau mendapatkan pendanaan dari kelompok investor yang kecil melalui modal ventura. Kedua pilihan tersebut memiliki konsekuensinya sendiri-sendiri. Menjual saham ke investor tunggal, misalnya kepada venture capitalists, memiliki keuntungan dalam hal rendahnya biaya produksi informasi.

Namun kelemahannya adalah venture capitalists memiliki daya tawar tinggi dibandingkan pemegang saham publik yang lebih tersebar, sehingga akan menuntut tingkat pengembalian yang lebih tinggi. Sebaliknya, menjual saham kepada kelompok investor yang lebih luas di pasar modal memiliki keuntungan karena kepemilikan saham yang lebih tersebar menyebabkan rendahnya daya tawar kelompok pemegang saham tersebut. Namun ada kelemahan, yaitu terjadinya duplikasi dalam produksi informasi yang menyebabkan perusahaan menanggung biaya informasi yang lebih besar. Hasil analisis yang dilakukan oleh Chemmanur dan Fulghieri menunjukkan bahwa solusi dari permasalahan ini tergantung dari besarnya biaya yang dikeluarkan oleh pihak luar dalam memproses informasi tentang perusahaan. Karena itu, perusahaan-perusahaan sebaiknya melakukan IPO hanya jika informasi-informasi tentang perusahaan tersebut telah terakumulasi dalam domain publik.Biaya yang dikeluarkan pihak luar untuk mengukur nilai perusahaan yang sebenarnya menjadi kecil, sehingga perusahaan-perusahan yang masih berusia muda disarankan untuk memilih venture capitalists. Singkatnya, semakin lama perusahaan berdiri, maka semakin rendah pula kesenjangan informasi antara perusahaan dengan pihak-pihak di luar perusahaan dan biayapendanaan semakin rendah.

Hasil analisis Chemmanur dan Fulghieri mengisyaratkan bahwa perusahaan harus mengeluarkan biaya pendanaan yang lebih tinggi pada masa awal berdirinya karena informasi tentang perusahaan belum tersedia secara luas di pasar. Informasi tentang kinerja perusahaan 
di masa lalu termasuk di dalamnya aktivitas pendanaan penting bagi pihak luar untuk mengestimasi tingkat pengembalian yang dapat diharapkan.Rekam jejak perusahaan dalam hal membayar utang di masa lalu bermanfaat bagi kreditur untuk menilai risiko ketidaktertagiahan yang menjadi dasar dalam menentukan tingkat bunga kredit.Perusahaan yang sering terlambat melunasi utangnya atau bahkan gagal bayar akan meningkatkan risiko ketaktertagihan,dan akan mendorong kreditur membebankan tingkat bunga yang lebih tinggi.

Akumulasi informasi yang tersedia di pasar membentuk reputasi perusahaan di mata investor atau kreditor. Reputasi yang baik menurunkan ketidakpastian dalam kemampuan perusahaan melunasi kredit, sehingga menurunkan tingkat bunga yang dibebankan.Jadi, perusahaan harus membangun reputasi baik yang baik untuk menurunkan biaya utang yang harus ditanggung perusahaan. Selain itu, reputasi yang baik juga menurunkan biaya utang pada saat menerbitkan obligasi.

Seperti yang telah dipaparkan sebelumnya, Datar et al. (1991) mengisyaratkan bahwa perusahaan-perusahaan yang baru berdiri dapat menyewa auditor untuk mengurangi ketidakpastian tentang kemampuan perusahaan dalam mengembalikan utang atau dalam memberi return yang memuaskan. Namun, laporan yang telah diaudit hanya mengungkapkan informasi yang telah diketahui oleh manajer, tetapi tidak memberikan informasi tambahan tentang nilai pasar perusahaan di masa mendatang.Peran utama auditing hanya sebagai atestasi, tidak lebih dari itu.Jadi, laporan audit tidak merefleksikan secara penuh informasi privat yang tentang nilai masa depan perusahaan, tetapi hanya mengurangi sebagian dari ketidakpastian tentang kinerja masa depan tersebut. Karena itu, perusahaan disarankan memberi sinyal yang lain untuk mengurangi sebagian dari ketidakpastian tersebut. Penjelasan yang dikemukakan oleh Dattar et al..menunjukkan bahwa menggunakan jasa auditor tidak sepenuhnya menghilangkan kesenjangan informasi antara manajer dan pihak di luar perusahaan.

Pittman dan Fortin (2004) berargumen bahwa perusahaan-perusahaan yang memiliki sejarah kredit yang panjang pada saat IPO mungkin tidak dapat mengurangi secara signifikan kesenjangan informasi yang terjadi dengan menyewa auditor Big N. Dengan bertambahnya umur perusahaan, perusahaan-perusahaan dapat mengandalkan reputasi baik yang mereka miliki untuk menurunkan tingkat bunga, sehingga manfaat yang diperoleh dari fungsi audit sebagai sebagai salah satu mekanisma monitoring menjadi berkurang.Hubungan antara lama perusahaan berdiri dengan kesenjangan informasi dapat terindikasi dari studi Ritter (1991). Menggunakan sampel perusahaan yang melakukan IPO tahun 1975 hingga tahun 1984, dia menguji fenomena underpricing yang selalu terjadi pada saat IPO. Hasil pengujian menunjukkan bahwa dalam jangka panjang saham-saham IPO menunjukkan kinerja yang buruk. Menurut Ritter, kecenderungan memburuknya kinerja saham IPO disebabkan oleh dua hal: pertama, investor terlalu optimis tentang potensi return dari perusahaan-perusahaan muda dan kedua, perusahaan memanfaatkan rasa optimis investor yang berlebihan untuk mendapatkan keuntungan. Namun, seiring berjalannya waktu, investor mendapat informasi yang lebih banyak tentang perusahaan dan harga saham berangsur-angsur menunjukkan nilai yang sebenarnya. Hasil penelitian Ritter (1991) memberikan bukti bahwa semakin lama perusahaan berdiri dan semakin banyak informasi yang tersedia di pasar, maka semakin rendah perbedaan persepsi nilai perusahaan antara perusahaan dan pelaku pasar.

Pittman dan Fortin (2004) menginterpretasikan temuan Ritter (1991) sebagai bukti bahwa kreditur mempersepsikan risiko kredit perusahaan-perusahaan yang belum memiliki sejarah privat yang panjang lebih besar daripada perusahaan yang memiliki sejarah privat yang panjang.Lebih jauh lagi mereka mengatakan bahwa kreditur mempelajari lebih banyak tentang perusahaanmuda setelah perusahaan menjadi perusahaan publik. Pada tahun-tahun awal tersebut, pengaruh auditor sangat besar dalam mengurangi biaya pinjaman. Namun, 
bertambahnya akumulasi informasi tentang perusahaan di pasar, dampak tersebut akan menurun.

Achek dan Gallali (2015) menguji pengaruh tipe auditor terhadap biaya utang pada perusahaan-perusahaan di Tunisia. Tipe auditor diukur dengan ukuran kantor akuntan yaitu Big 4 dan non Big 4. Hasil pengujian menunjukkan tipe auditor berhubungan negatif dengan biaya utang. Lebih jauh, mereka menemukan hubungan negatif antara tipe auditor dan biaya utang lebih kuat pada perusahaan-perusahaan publik dibanding perusahaan privat.

Causholli dan Knechel (2012) menguji pengaruh latar belakang lingkungan bisnis terhadap hubungan antara kualitas audit dan biaya utang. Hasil penelitian menunjukkan bahwa perusahaan-perusahaan yang masih berusia muda pada saat IPO membayar tingkat bunga yang lebih tinggi dan kualitas auditor berperan penting dalam menurunkan biaya utang. Lebih jauh mereka menemukan hubungan antara kualitas auditor dan umur perusahaan tergantung dari jenis industir. Dampak kualitas auditor terhadap penurunan biaya utang lebih besar pada perusahaan-perusahaan teknologi tinggi yang berusia muda dibandingkan perusahaan non teknologi yang berusia tua.

Berdasarkan argumen-argumen di atas, hubungan antara reputasi auditor dan biaya utang dapat dinyatakan sebagai berikut:

\section{H2a: Dampak reputasi auditor dalam menurunkan biaya utang akan semakin kuat pada perusahaan yang memiliki sejarah privat yang pendek. \\ H2b: Dampak reputasi auditor dalam menurunkan biaya utang pada perusahaan yang memiliki sejarah privat yang pendek akan berkurang lebih cepat seiring bertambahnya umur perusahaan.}

\section{METODA PENELITIAN}

\section{Populasi dan Sampel}

Populasi dalam penelitian ini adalah semua perusahaan yang terdaftar di Bursa Efek Indonesia. Sementara, sampel yang digunakan untuk menguji pengaruh reputasi auditor terhadap biaya utang adalah perusahaan yang tercatat di Bursa Efek Indonesia tahun 20032013. Daftar perusahaan yang melakukan IPO selama perioda penelitian diperoleh dari Fact Book yang diterbitkan oleh Bursa Efek Indonesia. Data bersumber dari laporan tahunan perusahaan yang dapat diakses melalui: 1) situs resmi Bursa Efek Indonesia dengan alamat www.bei.co.id, 2) Indonesian Capital Market Directory (ICMD) yang diterbitkan oleh Institute for Economic and Financial Research.

Pemilihan sampel dilakukan dengan purposive sampling dengan kriteria: 1) Semua perusahaanyang tercatat di Bursa Efek Indonesia secara berturut-turut dari tahun 2003 hingga tahun 2013, kecuali perusahaan yang masuk kelompok industri keuangan dan realestate. Industri keuangan dikeluarkan karena perusahaan-perusahaan yang beroperasi dalam industri yang sering menjadi objek regulasi pemerintah memiliki karakteristik yang berbeda dengan industri lain. Contohnya, skema jaminan deposito nasabah yang dipersyaratkan oleh undangundang perbankan nasional dapat mempengaruhi keputusan kredit perusahaanyang masuk dalam industri keuangan dan asuransi. Selain itu, definisi kewajiban dalam industri keuangan dan asuransi tidak dapat disamakan dengan definisi kewajiban perusahaan di luar industriindsutri tersebut. Regulasi tentang persyaratan modal minimum juga dapat mempengarui struktur modal industri tersebut. 2) Perusahaan-perusahaan yang melakukan IPO dari tahun 2003 hingga tahun 2012. Seperti yang telah dijelaskan pada bagian sebelumnya, penelitian ini menguji dampak reputasi perusahaan yang terbangun dari akumulasi informasi tentang perusahaan sepanjang waktu yang dapat diakses oleh penyedia modal. Penelitian ini mengasumsikan bahwa informasi tentang perusahaan akan lebih banyak tersedia setelah 
perusahaan menjadi perusahaan publik dan membatasi perusahaan yang melakukan IPO hanya pada perioda 2003-2012. Selanjutnya, dampak pertambahan umur setelah IPO diamati hingga tahun 2013. Penetapan tahun 2013 sebagai batas pengamatan tidak didasarkan pada argumen logis tertentu (arbriter) namun hanya berdasarkan asumsi bahwa minimal satu tahun setelah IPO pelaku pasar atau pemilik modal membentuk persepsi tentang reputasi perusahaan dalam mengembalikan pinjaman. 3) Laporan tahunan perusahaan sampel menyediakan secara lengkap informasi yang diperlukan untuk mengukur variabel-variabel penelitian.

Tabel 1. Prosedur Pemilihan Sampel

\begin{tabular}{|l|c|c|}
\hline \multicolumn{1}{|c|}{ Kriteria } & Setelah IPO & Sebelum IPO \\
\hline Perusahaan yang melakukan IPO 2003-2012 & 161 & 161 \\
\hline $\begin{array}{l}\text { Laporan keuangan tidak tersedia secara } \\
\text { lengkap dari sumber yang digunakan. }\end{array}$ & $(27)$ & $(27)$ \\
\hline Dihilangkan untuk memenuhi asumsi klasik & $(44)$ & $(3)$ \\
\hline Masuk kategori umur privat panjang & - & $(71)$ \\
\hline Sampel akhir & 90 & 63 \\
\hline
\end{tabular}

Table 1 menampilkan secara detail prosedur pemilihan sampel. Jumlah perusahaan sampel yang dapat dikumpulkan selama 2003-2012 adalah 161 perusahaan sesuai dengan jumlah perusahaan yang melakukan IPO tahun 2003-2012, dengan rincian sebagai berikut: tahun 2003 berjumlah 7 perusahaan, tahun 2004 berjumlah 10 perusahaan, tahun 2005 berjumlah9perusahaan, tahun 2006 berjumlah 13 perusahaan, tahun 2007 berjumlah 24 perusahaan, tahun 2008 berjumlah 19 perusahaan, tahun 2009 berjumlah 11 perusahaan, tahun 2010 berjumlah 21 perusahaan, tahun 2011 berjumlah 25 perusahaan, dan tahun 2012 berjumlah 22 perusahaan. Namun, sebanyak 44 perusahaan sampel sebelum IPO dan 3 perusahaan setealh IPO harus dieliminasi. Selanjutnya, sebanyak 27 perusahaan sampel harus dieliminasi karena data keuangan tidak tersedia. Proses eliminasi menyebabkan jumlah observasi yang tersedia untuk pengujian hipotesis sebelum dan setelah IPO masing-masing menjadi 90 dan 63 perusahaan.

\section{Pengukuran Variabel}

\section{Biaya utang (cost of debt)}

Variabel dependen dalam penelitian ini adalah biaya utang yang diukur dengan membagi biaya bunga dalam tahun tertentu dengan rata-rata utang jangka pendek dan jangka panjang. Formula pengukuran biaya utang yang digunakan dalam penelitian ini mengikuti Pittman dan Forti (2004).

\section{Umur perusahaan}

Hipotesis satu memprediksi biaya utang akan menurun seiring dengan meningkatnya umur perusahaan di pasar utang. Untuk menguji hipotesis satu $\left(\mathrm{H} 1_{\mathrm{A}}, \mathrm{H} 1_{\mathrm{B}}, \mathrm{H} 1_{\mathrm{C}}\right)$ penelitian ini mengikuti Pittman dan Fortin (2004) yang mengukur umur perusahaan dari jumlah tahun yang telah berlalu sejak perusahaan melakukan IPO. Sementara hipotesis dua $\left(\mathrm{H}_{2 \mathrm{~A}}\right.$ dan $\left.\mathrm{H}_{2 \mathrm{~B}}\right)$ menguji apakah perbedaan umur privat perusahaan menurunkan pengaruh auditor terhadap biaya utang. Untuk menguji $\mathrm{H}_{2 \mathrm{~A}}$ dan $\mathrm{H}_{2 \mathrm{~B}}$, umur perusahaan dihitung dari jumlah tahun yang telah berlalu dari pembentukan perusahaan hingga melakukan IPO. 


\section{Reputasi Auditor}

Setelah kantor akuntan Arthur Anderson dinyatakan bangkrut, kantor akuntan besar sebelumnya yang dikelompokkan sebagai The Big Fiveberkurang satu dan sekarang menjadi The Big Four. Dalam penelitian ini, kualitas auditor diproksikan dengan kantor-kantor akuntan di Indonesia yang berafiliasi dengan kantor akuntan The Big Four tahun 2004-2010 yaitu: Purwantono, Sarwoko, Sandjaja (Erns \& Young), Osman Bing Satrio (Deloitte), Sidharta, Sidharta, Widjaja (KPMG) dan Haryanto Sahari dan rekan (PWC).

\section{Variabel kontrol}

Dalam penelitian ini ada tiga variabel kontrol yang digunakan untuk mengurangi dampak perbedaan karakteristik perusahaan terhadap penetapan kebijakan utang: ukuran perusahaan, tingkat utang (leverage), dan tingkat arus kas operasi.Variabel kontrol dimasukkan untuk mengurangi kemungkinan terjadi error in variabel.

Ukuran perusahaan diukur dengan logaritma aset total dan variabel ini diprediksi berhubungan negatif dengan tingkat bunga. Carey et al..(1993) menunjukkan bahwa kreditor mempersepsikan perusahaan yang lebih besar memiliki risiko kredit yang lebih rendah. Sementara, tingkat utang yang diukur dengan total utang dibagi dengan ekuitas diprediksi berpengaruh positif terhadap tingkat bunga (Petersen dan Rajan, 1994). Variabel kontrol arus kas operasi diprediksi berhubungan negatif dengan biaya utang dan diukur dengan mendeflasi arus kas operasi terhadap aset total.

\section{Model Regresi}

\section{Pengujian Hipotesis Satu dan Dua}

Model berikut ini digunakan untuk menguji pengaruh reputasi auditor terhadap biaya utang:

Keterangan:

$$
\begin{aligned}
& \text { Biaya_Utang }{ }_{i t}=\beta_{0}+\beta_{1} \text { Aud }_{i t}+\beta_{2} \text { Umur }_{i t}+\beta_{3} \text { Aud }^{*} \text { Umur }_{i t}+\beta_{4} \text { Size }_{i t}+\beta_{5} \text { LeV }_{i t}+ \\
& \beta_{7} \mathrm{CFO}_{\text {it }}+\varepsilon_{\text {it }}
\end{aligned}
$$

- Biaya_Utang = Tingkat bunga yang diukur dengan biaya bunga dibagi dengan rata-rata utang jangka pendek dan jangka panjang.

- $\quad$ Aud = Variabel dummy bernilai 1 jika kantor akuntan berafiliasi denganBig Four dan 0 jika lainnya.

- Umur = Untuk menguji hipotesis $\mathrm{H}_{1 \mathrm{~A}}, \mathrm{H}_{1 \mathrm{~B}}, \mathrm{H}_{1 \mathrm{C}}$ umur diukur dari jumlah tahunsetelah IPO. Untuk menguji $\mathrm{H}_{2 \mathrm{~A}}$ dan $\mathrm{H}_{2 \mathrm{~B}}$ umur diukur darisaat perusahaan berdiri hingga melakukan IPO

- $\quad$ Aud*Umur = Variabel interaksi yang merupakan perkalian antara variabel auditor dan umur perusahaan.

- $\quad$ Lev = Tingkat utang yang diukur dari hasil bagi total utang dan ekuitas

- Size = Ukuran perusahaan yang merupakan logaritma aset total.

- $\quad \mathrm{CFO}=$ Arus kas operasi dideflasi dengan aset total.

Seluruh pengujian hipotesis dilakukan dengan analisis regresi linear ganda. Regresi linear ganda mengharuskan distribusi residual memenuhi asumsi-asumsi yang mendasari regresi linear seperti normalitas, kolinearitas, heteroskedastisitas dan autokorelasi. Karena itu, adanya perbedaan jumlah observasi satu pengujian hipotesis ke pengujian hipotesis lainnya tidak dapat dihindari demi memenuhi asumsi klasik. 


\section{HASIL DAN PEMBAHASAN}

\section{Statistik Deskriptif}

Selama perioda 2003-2013 ada 134 perusahaan yang memenuhi kualifikasi sampel dan dapat diakses dari sumber data yang digunakan. Dari jumlah tersebut, terdapat 44 perusahaan yang harus dieliminasi untuk memenuhi asumsi klasik yang mendasari regresi berganda (lihat lampiran). Tabel 2 menampilkan ringkasan statistik variabel biaya utang, karakteristik perusahaan dan reputasi auditor. Dari tabel dapat dilihat biaya utang berada pada rentang $4 \%$ hingga $27 \%$ dengan rerata $12,3 \%$. Ini menunjukkan bahwa secara rerata biaya utang yang dibayarkan perusahaan mendekati tingkat normal suku bunga yang berlaku di Indonesia antara $10 \%$ hingga $14 \%$.

Tabel 2. Ringkasan Statistik

\begin{tabular}{|l|l|l|l|l|l|l|}
\hline Variabel & N & Rerata & Median & $\begin{array}{l}\text { Dev } \\
\text { Std }\end{array}$ & Min & Maks \\
\hline Biaya_utang & 90 & 0,123 & 0,120 & 0,051 & 0,040 & 0,27 \\
\hline Umur & 90 & 4,367 & 4,00 & 2,616 & 1,000 & 10,00 \\
\hline Auditor & 90 & 0,411 & 0,00 & 0,495 & 0,000 & 1,00 \\
\hline Leverage & 90 & 1,933 & 0,875 & 2,858 & 0,070 & 17,920 \\
\hline Size & 90 & 11,928 & 12,090 & 0,188 & 7,78 & 14,400 \\
\hline Arus_Kas & 90 & 0,034 & 0,030 & 0,111 & - & 0,260 \\
& & & & & 0,330 & \\
\hline
\end{tabular}

Variabel umur yang mencerminkan jumlah tahun yang berlalu setelah perusahaan mencatatkan sahamya di Bursa Efek Indonesia berkisar antara 1 hingga 10 tahun dengan rerata 4,367 tahun. Rerata rentang tahun yang ditunjukkan dalam tabel 4.1menunjukkan bahwa perusahaan sampel yang digunakan memiliki umur 4-5 tahun setelah melakukan IPO dan ini disebabkan kualifikasi pemilihan sampel yang menetapkan bahwa perusahaan harus memiliki minimal satu tahun setelah IPO agar pelaku pasar dapat mempelajari reputasi perusahaan. Sementara, dari 90 sampel yang digunakan sebanyak 41,1\% menggunakan auditor yang berafiliasi dengan Big Four. Khusus untuk variabel yang mencerminkan karakteristik perusahaan (leverage, size, Arus kas), tabel 2 menunjukkan bahwa secara umum sampel perusahaan yang digunakan berasal dari perusahaan yang memiliki tingkat utang, arus kas dan ukuran perusahaan moderat.

\section{Pengujian Hipotesis dan Pembahasan}

\section{Umur Setelah IPO dan Reputasi Auditor}

Hipotesis satu menguji dampak reputasi perusahaan dan auditor terhadap biaya utang perusahaan setelah perusahaan melakukan IPO.Secara spesifik, $\mathrm{H} 1_{\mathrm{A}}$ memprediksi seiring dengan berjalannya waktu, biaya utang yang dibebankan kepada perusahaan akan semakin menurun. Ini bisa terjadi karena pasar memiliki rekam jejak perusahaan yang memungkinkan untuk menilai kemampuan perusahaan melunasi kewajiban-kewajibannya. Sementara, efek reputasi auditor terhadap biaya utang diprediksi menurun sepanjang waktu. Hal ini disebabkan pengenalan pasar yang semakin mendalam atas kinerja keuangan dan kemampuannya membayar utang tanpa harus mengandalkan laporan auditor yang memeriksa laporan keuangan. Hubungan ini dinyatakan dalam $\mathrm{H}_{\mathrm{B}}$. Interaksi antara auditor dan umur perusahaan (setelah IPO) dinyatakan dalam $\mathrm{H} 1_{\mathrm{C}}$. Hasil pengujian $\mathrm{H} 1_{\mathrm{A}}, \mathrm{H} 1_{\mathrm{B}}$ dan $\mathrm{H} 1_{\mathrm{C}}$ 
menggunakan analisis regresi berganda dapat dilihat pada tabel 3. Sebagai catatan, hasil pengujian regresi dilakukan dengan satu sisi (one-tailed).

Tabel 3. Pengaruh Auditor dan Karakteristik Perusahaan Terhadap Biaya Utang.

\begin{tabular}{|c|c|c|c|c|c|}
\hline \multirow[b]{2}{*}{ Variabel } & \multicolumn{2}{|c|}{ Koefisien } & \multirow[b]{2}{*}{$\mathrm{T}$} & \multirow[b]{2}{*}{ P-value } & \multirow[t]{2}{*}{ Kesimpulan } \\
\hline & $\beta$ & Std. Error & & & \\
\hline INTERSEP & 0,059 & 0,059 & 0,996 & 0,161 & \\
\hline UMUR & 0,009 & 0,003 & 3,221 & 0,001 & Ditolak \\
\hline AUDITOR & 0,025 & 0,020 & 1,249 & 0,107 & Ditolak \\
\hline AUD*UMUR & $-0,010$ & 0,004 & $-2,547$ & 0,006 & Ditolak \\
\hline LEVERAGE & 0,001 & 0,002 & 0,251 & 0,401 & Ditolak \\
\hline SIZE & 0,003 & 0,005 & 0,610 & 0,272 & Ditolak \\
\hline CFO & $-0,089$ & 0,047 & $-1,898$ & 0,031 & Diterima \\
\hline
\end{tabular}

Dari Tabel 3 dapat dilihat variabel UMUR berpengaruh positif signifikan terhadap biaya utang pada level kurang dari $1 \%$. Walaupun signifikan secara statistik, arah yang ditemukan tidak sesuai dengan yang diprediksi. Secara konseptual, reputasi perusahaan yang terbangun dengan berjalannya waktu dapat menurunkan risiko ketidaktertagihan (default risk) karena kreditor memiliki informasi yang cukup untuk menilai kondisi keuangan perusahaan.Jadi variabel UMUR diprediksi memiliki arah negatif. Ternyata hasil analisis regresi menunjukkan arah yang sebaliknya. Ini tidak konsisten dengan temuan Pittman dan Fortin (2004) yang menunjukkan bahwa dengan bertambahnya umur perusahaan, akumulasi informasi tentang perusahaan di pasar semakin banyak dan akhirnya akan menurunkan tingkat bunga yang dibebankan kepada perusahaan. Arah positif yang ditemukan dalam penelitian ini menunjukkan bahwa semakin panjang tahun yang berlalu sejak perusahaan melakukan IPO, semakin tinggi pula biaya utang yang harus dibayar perusahaan. Berdasarkan temuan ini, $\mathrm{H} 1_{\mathrm{A}}$ tidak terdukung secara statistis.

Hasil temuan yang tidak konsisten dengan yang diprediksi mungkin disebabkan perioda penelitian yang terlalu pendek sehingga rentang waktu setelah perusahaan melakukan IPO tidak cukup untuk menilai reputasi perusahaan. Dari statistik deskriptif yang telah dijelaskan sebelumnya, tahun yang berlalu setelah IPO memiliki rerata 4,367 tahun. Rentang waktu sesingkat ini belum cukup bagi pasar untuk menilai reputasi perusahaan dalam mengembalikan kewajiban-kewajibannya. Rentang waktu yang singkat tersebut dipengaruhi oleh pemilihan perioda penelitian yang hanya 10 tahun. Jika rentang waktu yang digunakan lebih dari 10 tahun, rerata umur perusahaan setelah IPO juga akan lebih panjang dan kemungkinan hasil yang diperoleh juga berbeda. Sementara, pengaruh reputasi auditor terhadap biaya utang yang diwakili variabel AUDITOR tidak signifikan secara statistik dengan $p$-value 0,107. Hasil yang tidak signifikan ini menunjukkan bahwa kreditur tidak mempertimbangkan siapa auditor yang mengaudit laporan keuangan perusahaan. Dengan demikian hipotesis $\mathrm{H}_{1}$ в tidak terdukung secara statistik.Hasil ini tidak konsisten dengan Kim et al., (2011) dan Pittman dan Fortin (2004).Gagalnya penelitian ini mendeteksi hubungan negatif reputasi auditor dan biaya utang bisa jadi disebabkan oleh kinerja keuangan yang tidak mendukung. Tampaknya kreditur lebih mementingkan angka-angka yang tersaji dalam laporan keuangan dengan asumsi bahwa laporan keuangan yang diaudit oleh auditor independen sudah pasti dapat diandalkan tanpa harus memperhatikan reputasi kantor akuntan yang melakukan audit.

Masih dari Tabel 3, variabel AUD*UMUR yang merupakan variabel interaksi antara kualitas auditor yang digunakan perusahaan (AUDITOR) dan waktu yang berlalu setelah mencatatkan saham di pasar modal (UMUR) memiliki arah negatif dan signifikan pada level 
5\%.Hasil ini tidak sesuai dengan $\mathrm{H} 1_{\mathrm{C}}$ yang memprediksi hubungan kedua variabel memiliki arah positif.Karena itu, $\mathrm{H} 1_{\mathrm{C}}$ tidak terdukung secara statistis. Arah negatif menunjukkan bahwa dengan berjalannya waktu, perusahaan yang diaudit oleh kantor akuntan yang berafiliasi dengan Big Four dibebankan biaya utang yang lebih rendah dibandingkan perusahaan yang tidak diaudit KAP yang lain. Argumen yang digunakan sebelumnya untuk menjelaskan perbedaan arah koefisien variabel UMUR antara yang diprediksi dengan yang aktual juga dipercaya menjadi penyebab ketidakkonsistenan arah koefisien AUD*UMUR dengan yang diprediksi. Secara konseptual, variabel interaksi AUD*UMUR diprediksi memiliki koefisien regresi positif karena penurunan biaya utang perusahaan yang diaudit oleh Auditor yang memiliki reputasi tinggi akan lebih kecil daripada penurunan biaya utang perusahaan yang diaudit oleh auditor yang belum memiliki reputasi tinggi. Namun, hasil analisis regresi hubungan antara UMUR dan Biaya Utang yang disinggung sebelumnya menunjukkan arah positif. Karena itu tidak mengherankan jika koefisien interaksi AUD*UMUR yang ditemukan dalam penelitian ini memiliki arah negatif.

Khusus variabel karakteristik perusahaan yang digunakan sebagai variabel kontrol hanya variabel arus kas (CFO) yang signifikan, sedangkan ukuran perusahaan dan tingkat utang tidak signifikan secara statistik. Ini artinya, perusahaan-perusahaan yang digunakan sebagai sampel memiliki karakteristik yang hampir sama dalam hal ukuran dan risiko perusahaan.

\section{Umur Sebelum IPO dan Reputasi Auditor (Sampel Privat Pendek)}

Di samping menguji dampak umur perusahaan dan reputasi auditor yang digunakan perusahaan setelah mencatatkan saham di pasar modal, penelitian ini juga menguji dampak kedua variabel terhadap biaya utang sejak dari perusahaan berdiri. Pengujian dilakukan dengan memisahkan perusahaan ke dalam dua kelompok berdasarkan umur perusahaan. Perusahaan yang memiliki umur dibawah median, dikelompokkan sebagai perusahaan dengan sejarah privat yang pendek dan perusahaan yang memiliki umur di atas median dikelompokkan sebagai perusahaan dengan sejarah privat yang panjang. Dari total sampel sebanyak 134 perusahaan, ada 63 perusahaan yang memiliki sejarah privat pendek dan 71 perusahaan memiliki sejarah privat panjang.

Dari 63 perusahaan yang memiliki sejarah privat pendek, sebanyak 3 perusahaan harus dieliminasi untuk memenuhi asumsi normalitas. Hasil analisis regresi yang menguji pengaruh auditor dan umur perusahaan terhadap biaya utang dapat dilihat pada tabel 4. Perlu dicatat bahwa pengujian hipotesis dilakukan dengan satu sisi (one-tailed). Dari tabel dapat dilihat, umur perusahaan tidak berpengaruh signifikan terhadap biaya utang. Hasil ini mengindikasikan bahwa reputasi perusahaan dalam mengembalikan pinjaman tidak dapat terbentuk dalam waktu yang singkat.Tampaknya pelaku pasar membutuhkan waktu yang panjang untuk membangun kepercayaan atas kemampuan keuangan perusahaan.

Sementara, dari Tabel 4 dapat dilihat reputasi auditor berpengaruh negatif terhadap biaya utang pada level 5\%. Ini artinya, biaya utang perusahaan yang diaudit oleh auditor yang berafiliasi dengan Big Four dan memiliki sejarah privat yang pendek lebih rendah daripada yang diaudit oleh auditor lain. Namun, hal yang sama tidak teridentifikasi pada perusahaan yang memiliki sejarah privat yang panjang (Tabel 5). Hasil analisis regresi dampak reputasi auditor pada kelompok sampel yang memiliki sejarah privat panjang menunjukkan hasil yang tidak signifikan. Perbandingan kedua hasil ini menunjukkan pengaruh reputasi auditor terhadap biaya utang hanya efektif pada perusahaan yang memiliki umur privat pendek. Dengan demikian, hipotesis $\mathrm{H} 2 \mathrm{~A}$ yang memprediksi pengaruh auditor terhadap biaya utang lebih kuat pada perusahaan yang memiliki umur privat pendek terdukung secara statistik. Hasil ini konsisten dengan Pittman dan Fortin (2004). 
Analisis lanjutan untuk mengetahui apakah pengaruh auditor terhadap biaya utang, seperti yang dinyatakan dalam hipotesis $\mathrm{H} 2 \mathrm{~B}$, pada perusahaan dengan umur privat pendek mengalami penurunan sepanjang waktu dilakukan dengan memasukkan variabel interaksi AUD*UMUR. Koefisien interaksi yang bernilai positif digunakan sebagai dasar penyimpulan bahwa pengaruh reputasi auditor menurun seiring berjalannya waktu. Tabel 4 mengkonfirmasi dugaan yang dinyatakan dalam hipotesis $\mathrm{H} 2{ }_{\mathrm{B}}$ dengan tingkat

Tabel 4. Pengaruh Auditor dan Karakteristik Perusahaan Untuk Sampel Privat Pendek

\begin{tabular}{|c|c|c|c|c|c|}
\hline \multirow[b]{2}{*}{ Variabel } & \multicolumn{2}{|c|}{ Koefisien } & \multirow[b]{2}{*}{$\mathrm{t}$} & \multirow[b]{2}{*}{ P-value } & \multirow[t]{2}{*}{ Kesimpulan } \\
\hline & $\beta$ & Std. Error & & & \\
\hline INTERSEP & ,008 & 109 & ,074 & 0,471 & \\
\hline UMUR & ,000 & ,004 & ,066 & 0,474 & Ditolak \\
\hline AUD &,- 079 & ,045 & $-1,764$ & 0,042 & Diterima \\
\hline AUD*UMUR & ,013 & ,006 & 2,223 & 0,016 & Diterima \\
\hline LEV & ,001 & ,006 & ,083 & 0,467 & Ditolak \\
\hline SIZE & ,009 & 009 & 998 & 0,161 & Ditolak \\
\hline CFO &,- 059 &, 050 & $-1,174$ & 0,123 & Ditolak \\
\hline
\end{tabular}

signifikansi 5\% (one-tailed test). Arah positif mengindikasi bahwa pengaruh negatif auditor yang berafiliasi dengan Big Four terhadap biaya utang lebih kecil daripada pengaruh negatif perusahaan yang tidak berafiliasi dengan Big Four. Pembahasan lebih detail perbedaan dua koefisien menggunakan variabel dummy dapat dilihat di Gujarati (2002). Sebagai tambahan, tabel 4 menunjukkan bahwa tidak satupun variabel kontrol yang digunakan berpengaruh signifikan terhadap biaya utang.

\section{Umur Sebelum IPO dan Reputasi Auditor (Sampel Privat Panjang)}

Untuk memperoleh pemahaman yang lebih jauh tentang hubungan umur perusahaan dan reputasi auditor, penelitian ini juga menguji kelompok sampel yang termasuk dalam perusahaan yang memiliki sejarah privat panjang. Hasil pengujian regresi pada perusahaan yang memiliki umur sebelum IPO yang panjang tersaji pada Tabel 5. Sama seperti yang ditemukan menggunakan sampel privat yang pendek, umur perusahaan pada perusahaan yang memiliki umur privat yang tinggi tidak berpengaruh signifikan terhadap biaya utang. Hasil yang tidak signifikan ini mungkin disebabkan kurangnya informasi yang dapat diakses pelaku pasar untuk menilai kemampuan perusahaan dalam melunasi utangnya.

Seperti yang telah diketahui, perusahaan privat tidak diwajibkan untuk merilis kinerja laba dan posisi keuangan secara publik. Akibatnya, pasar mengalami kesulitan dalam membangun kepercayaan terhadap perusahaan walaupun telah lama berdiri.Namun perlu diingat, hasil pengujian hipotesis satu sebelumnya yang berfokus pada hubungan biaya utang dan umur setelah IPO menunjukkan hubungan positif signifikan dan arahnya tidak konsisten dengan yang diprediksi. Karena itu, argumen tentang kurangnya informasi yang beredar tentang perusahaan privat untuk menjelaskan hasil yang tidak signifikan perlu diuji lebih lanjut dengan memperpanjang perioda setelah IPO untuk memastikan bahwa pelaku pasar memiliki waktu yang cukup untuk membangun kepercayaan tentang kondisi keuangan perusahaan.Sebelum ini dilakukan, kita hanya bisa menduga bahwa hasil yang tidak konsisten dengan prediksi teori disebabkan perioda penelitian yang pendek.

Berkaitan dengan reputasi auditor, Tabel 5 menunjukkan reputasi auditor tidak berpengaruh signifikan terhadap biaya utang. Hasil ini berbeda dengan kelompok sampel dengan umur privat pendek yang ditampilkan dalam Tabel 4 sebelumnya yang menunjukkan 
adanya hubungan negatif antara reputasi auditor dan biaya utang. Hasil yang tidak signifikan ini menunjukkan bahwa pengaruh reputasi auditor terhadap biaya utang hanya terlihat pada perusahaan privat yang baru berdiri yang membutuhkan auditor yang berkualitas untuk menjamin kredibilitas laporan keuangan. Sedangkan perusahaan privat yang telah lama berdiri tidak membutuhkan dukungan auditor dalam menambah keyakinan pengguna laporan keuangan karena reputasi yang terbangun selama ini menjadi jaminan keandalan laporan keuangan. Secara keseluruhan, temuan ini tidak konsisten dengan Achek dan Gallali (2015) yang berhasil mendeteksi pengaruh negatif kualitas auditor terhadap biaya utang pada perusahaan publik dan privat. Sementara itu, dari tabel 5 dapat dilihat bahwa tidak ada satupun dari variabel kontrol yang berpengaruh signifikan.

Tabel 5. Pengaruh Auditor dan Karakteristik Perusahaan Untuk Sampel Privat Panjang

\begin{tabular}{|c|c|c|c|c|c|}
\hline \multirow[b]{2}{*}{ Variabel } & \multicolumn{2}{|c|}{ Koefisien } & \multirow[b]{2}{*}{$\mathrm{t}$} & \multirow[b]{2}{*}{ Sig. } & \multirow{2}{*}{ Kesimpulan } \\
\hline & $\beta$ & Std. Error & & & \\
\hline INTERSEP & ,202 & ,085 & 2,386 &, 020 & \\
\hline UMUR &,- 001 & 001 &,- 580 & ,564 & Ditolak \\
\hline AUD &,- 043 & ,045 &,- 953 & 344 & Ditolak \\
\hline AUD*UMUR & ,002 & 002 & 926 & 358 & Ditolak \\
\hline LEV & ,003 & ,003 & 1,028 & 308 & Ditolak \\
\hline SIZE & -,007 & 007 & $-1,019$ & 312 & Ditolak \\
\hline CFO & 013 & ,009 & 1,487 & 142 & Ditolak \\
\hline
\end{tabular}

\section{SIMPULAN, KETERBATASAN DAN SARAN}

\section{Simpulan}

Penelitian ini menguji peran reputasi perusahaan dan auditor dalam mengurangi biaya utang perusahaan. Lebih spesifik, penelitian ini menguji dampak kualitas auditor dalam menurunkan biaya utang dengan mempertimbangkan sejarah privat perusahaan. Semakin panjang umur perusahaan, maka dapat diharapkan semakin banyak pula informasi tentang perusahaan yang tersedia di pasar. Pengalaman-pengalamam perusahaan di masa lalu digunakan kreditur untuk menilai kemampuan perusahaan menangani proyek-proyek yang berisiko dan memenuhi tagihan-tagihan yang telah jatuh tempo. Reputasi yang baik berkontribusi dalam menurunkan tingkat bunga.

Namun, hasil pengujian menggunakan sampel perusahaan yang terdaftar di Bursa Efek Indonesia tahun 2003-2013 tidak konsisten dengan yang diprediksi. Analisis regresi menunjukkan bahwa biaya utang mengalami peningkatan seiring bertambahnya umur perusahaan semenjak melakukan IPO. Hasil yang membingungkan ini mungkin disebabkan perioda penelitian setelah perusahaan melakukan IPO terlalu pendek.Akibatnya, pasar belum memiliki informasi yang cukup dalam membangun kepercayaan terhadap kemampuan perusahaan mengembalikan pinjaman.

Literatur keuangan juga mengisyaratkan bahwa perusahaan tidak harus menunggu terlalu lama untuk mendapatkan kepercayaan kreditur.Salah satu yang dianjurkan adalah dengan memberikan sinyal ke pasar tentang prospek perusahaan sesungguhnya.Dari banyak alternatif sinyal yang dapat digunakan, salah satunya adalah memilih auditor yang memiliki reputasi yang tinggi.Dengan memilih auditor yang bereputasi tinggi perusahaan memberi 
sinyal kepada pengguna laporan keuangan bahwa perusahaan telah melaporkan setiap peristiwa ekonomi yang terjadi sesuai dengan fakta.Bagi kreditur, pemilihan auditor yang bereputasi tinggi memberi keyakinan tentang keandalan angka-angka yang tersaji, meningkatkan keyakinan tentang kemampuan perusahaan mengembalikan pinjaman, dan menjadi bahan pertimbangan dalam menurunkan tingkat bunga yang dibebankan. Namun tidak seperti prediksi, hasil analisis regresi yang menguji dampak reputasi auditor terhadap biaya utang setelah perusahaan melakukan IPO gagal mengidentifikasi hubungan antara kedua variabel ini.Namun, hasil yang sebaliknya ditemukan pada sampel perusahaan sebelum IPO.Hasil pengujian menunjukkan bahwa reputasi auditor berpengaruh negatif signifikan terhadap biaya utang.

Seiring bertambahnya umur perusahaan, maka semakin banyak pula informasi yang dimiliki kreditur tentang perusahaan, termasuk sejarak kredit perusahaan.Perusahaan dengan kredit yang panjang pada saat IPO atau setelah IPO mungkin tidak dapat menurunkan lebih jauh lagi kesenjangan informasi antara perusahaan dan kreditur dengan menyewa auditor yang memiliki reputasi tinggi. Dengan bertambahnya umur perusahaan, perusahaanperusahaan dapat mengandalkan reputasi baik yang mereka miliki untuk menurunkan tingkat bunga, sehingga manfaat yang diperoleh dari fungsi audit sebagai sebagai salah satu mekanisma monitoring menjadi berkurang.

Studi ini menemukan, interaksi antara umur perusahaan dan reputasi auditor hanya teridentifikasi sebelum perusahaan melakukan IPO, khususnya pada kelompok perusahaan yang memiliki sejarah privat yang pendek. Sedangkan untuk perusahaan yang memiliki sejarah privat yang panjang, penelitian ini gagal menemukan hubungan yang signifikan.Begitu pula untuk perioda waktu setelah IPO. Interaksi antara umur dan reputasi auditor tidak berpengaruh signifikan terhadap biaya utang.

\section{Keterbatasan dan Saran}

Generalisasi terhadap hasil penelitian perlu dilakukan secara hati-hati. Penelitian ini menggunakan sampel perusahaan yang melakukan IPO tahun 2003-2012 dengan cut off tahun 2013. Artinya, perusahaan yang melakukan IPO tahun 2012 hanya memiliki satu tahun untuk mengukur dampak reputasi auditor dan umur terhadap biaya utang. Kegagalan dalam mengidentifikasi dampak umur perusahaan dan reputasi auditor setelah IPO mungkin bersumber dari perioda penelitian yang terlalu pendek. Rerata umur perusahaan setelah IPO yang digunakan sebagai sampel hanya 4,367 tahun. Rentang waktu sependek ini mungkin belum cukup bagi kreditur untuk membangun kepercayaan terhadap perusahaan. Oleh karena itu, penelitian-penelitian berikutnya dapat memperpanjang perioda penelitian, misalnya menguji perusahaan yang melakukan IPO tahun 2000-2005 dengan cut off 2015. Dengan rentang waktu seperti ini, perusahaan sampel memiliki umur setelah IPO paling pendek 10 tahun. 


\section{DAFTAR PUSTAKA}

Achek, I., and M.I. Gallali. 2015. Audit Quality, Timely Disclosure, and The Cost of Debt: Tunisian Evidence. Journal of Modern Accounting and Auditing 11 (4): 194-209.

Beatty, R.P. 1989. Auditor Reputation and The Pricing of Initial Public Offerings. The Accounting Review 64 (4): 693-709.

Becker, C., DeFond, M.L., Jiambalvo, J., and K.R. Subramanyam. 1998. The Effect of Audit Quality on Earnings Management.Contemporary Accounting Research 15: 1-24.

Boone, J., I. Khurana, and K. Raman. 2012. Audit Market Concentration and Auditor Tolerance of Earnings Management. Contemporary Accounting Research 29 (4): 1171-1203.

Chan, A.L.C., and A.W. Hsu. 2013. Corporate Pyramids, Concervatism and Cost of Debt: Evidence From Taiwan. The International Journal Of Accounting.

Chen C., and S. Zhu. 2013. Financial Reporting Quality, Debt Maturity, and the Cost of Debt: Evidence from China. Emerging Markets Finance and Trade 49 (4): 236-253.

Chemmanur, T.J., and P. Fulghieri. 1999. A Theory of The Going Concern Decision. Review of Financial Studies 12: 249-279.

Copley, P.A., and E.B. Douthett. 2002. The Association Between Auditor Choice, Ownership Retained, andEarnings Disclosure by Firms Making Initial Public Offerings. Contemporary Accounting Research 19: 49-75.

Causholli, M., and W.B. Knechel. 2012. Lending Relationship, Auditor Quality and debt Cost. Managerial Auditing Journal 27 (6): 550-572.

Datar, S.M., G.A. Feltham, and J.S. Hughes. 1991. The Role of Audits and Audit Quality in valuing newissues. Journal of Accounting and Economics 14: 3-49.

DeAngelo, L.E. 1981. Auditor Size and Audit Quality.Journal of Accounting and Economics 3, 183-199.

DeFond, M., dan J. Jiambalvo. 1994. Debt Covenant Violation and Manipulation of Accruals. Journal of Accounting and Economics 17, 145-176.

Dhaliwal, D.S., C.A. Gleason, C.A. Heitzman, S., and K.D. Melendrez. 2008. Auditor Fees and Cost of Debt. Journal of Accounting, Auditing \&Finance 23 (1) : 122.

Diamond, D.W. 1989.Reputation Acquisition in Debt Markets.Journal of Political Economy 97, 828-862.

Dye, R.A., 1993.Auditing Standards, Legal Liability and Auditor Wealth.Journal of Political Economy 101: 887-914.

Fortin, S., dan J.A. Pittman. 2007. The role of auditor choice in debt pricing in private firms. Contemporary Accounting Research 24: 859-96.

Francis, J.R., E.L. Maydew, and H.C. Sparks. 1999. The Role of Big 6 Auditors in The Credible Reporting of Accruals.Auditing. A Journal of Practice and Theory 18: 1734.

Jensen, M. C., and W. H. Meckling. 1976. Theory of The Firm: Managerial Behavior, Agency Costs and Ownership Structure. Journal of Financial Economics 3(4), 305360. 
Karjalainen, J. 2011. Audit Quality and Cost of Debt Capital for Private firms: Evidence From Finland. International Journal Of Auditing 15: 88-108.

Kim, J. B., D. A. Simunic, M. T. Stein, and C. H. Yi. 2011. Voluntary Audits and the Cost of Debt Capital for Privately Held Firms: Korean Evidence. Contemporary accounting research 28(2): 585-615.

Lang, M., 1991. Time-Varying Stock Price Response to Earnings Induced by Uncertainty About The Time Series Process of Earnings. Journal of Accounting Research 29, 229-257.

Levine, R., and S. Zervos. 1998. Stock Markets, Banks and Economic Growth." American Economic Review 88, 537-558.

Mansi, S.A., W.F. Maxwell, and D.P. Miller. 2004. Does auditor quality and tenure matter to investors? Evidence from the bond market. Journal of Accounting Research 42 (September): 755-93.

Palmrose, Z. 1988. Analysis of Auditor Litigation and Audit Service Quality.The Accounting Review 63, 55-73.

Pittman, J.A., and S. Fortin. 2004. Auditor Choice and The Cost of Debt Capital for Newly Public Firms. Journal of Accounting and Economics 37: 113-136.

Quick, R. 2012. EC Green Paper Proposals and Audit Quality.Accounting in Europe 9(1): 1738.

Rajan, R., and L. Zingales. 1998.Financial Dependence and Growth. The American Economic Review 88, 559-586.

Ritter, J.R., 1991. The Long-Run Performance of Initial Public Offerings. Journal of Finance $46,3-27$.

Stiglitz, J.E., and A. Weiss. 1981. Credit Rationing in Markets With Imperfect Information. The American Economic Review 71, 393-410.

Sundem, G. L., R. E. Dukes, and J. A. Elliott. 1996. The Value of Information and Audits.Coopers \& Lybrand.

Sweeney, A. 1994. Debt Covenant Violations and Managers' Responses.Journal of Accounting and Economics 17: 281-308.

Teoh, S.H., T.J. Wong. 1993. Perceived Auditor Quality and The Earnings Response Coefficient. The Accounting Review 68: 346-366.

Vander B. H., M.. De Meyere, and C. Dan Van. 2015. P. Small Bus Econ (2015) 45: 149. https://doi.org/10.1007/s11187-015-9645-1 


\section{LAMPIRAN 1.PENGUJIAN ASUMSI KLASIK (HIPOTESIS SATU/ SETELAH IPO)}

\section{Tests of Normality}

\begin{tabular}{lccccccc}
\hline \hline & \multicolumn{4}{c}{ Kolmogorov-Smirnova } & & \multicolumn{2}{c}{ Shapiro-Wilk } \\
\cline { 2 - 9 } & Statistic & df & Sig. & Statistic & df & Sig. \\
\hline Unstandardized Residual & ,077 & 90 &, $200^{*}$ &, 979 & 90 &, 150 \\
\hline \hline
\end{tabular}

a. Lilliefors Significance Correction

*. This is a lower bound of the true significance.

Model Summary

\begin{tabular}{|c|c|c|c|c|c|c|c|}
\hline Model & $\mathrm{R}$ & R Square & $\begin{array}{l}\text { usted R } \\
\text { quare } \\
\end{array}$ & $\begin{array}{l}\text { Std. Error of } \\
\text { the Estimate }\end{array}$ & Durb & n-Watson & \\
\hline 1 &, $450^{a}$ & ,203 &, 145 & ,04689 & & 1,934 & \\
\hline $\begin{array}{l}\text { a. Prec } \\
\text { b. Dep }\end{array}$ & $\begin{array}{l}\text { ictors: (Const } \\
\text { endent Variab }\end{array}$ & $\begin{array}{l}\text { tant), CFO, UMU } \\
\text { el: BUNGA }\end{array}$ & _IPO, AUDI & ITOR, SIZE, LI & /ERAGE & AUDXIPO & \\
\hline & & Unstandardize & Coefficients & & & Collinearity & atistics \\
\hline Model & & B & Std. Error & $\mathrm{t}$ & Sig. & Tolerance & VIF \\
\hline 1 & (Constant) & ,059 & ,059 & ,996 & ,322 & & \\
\hline & UMUR_IPO & ,009 &, 003 & 3,221 & ,002 & ,501 & 1,997 \\
\hline & AUDITOR & ,025 & ,020 & 1,249 & 215 & ,256 & 3,904 \\
\hline & AUDXIPO &,- 010 & ,004 & $-2,547$ & ,013 & , 191 & 5,233 \\
\hline & LEVERAGE & ,001 &, 002 & ,251 & ,802 & ,694 & 1,440 \\
\hline & SIZE & ,003 & ,005 & ,610 &, 544 & ,734 & 1,363 \\
\hline & CFO &,- 089 &, 047 & $-1,898$ &, 061 & ,921 & 1,086 \\
\hline
\end{tabular}

LAMPIRAN 2. ASUMSI KLASIK (HIPOTESIS DUA / SAMPEL PRIVAT PENDEK) Tests of Normality

\begin{tabular}{|l|r|r|r|r|r|c|}
\hline & \multicolumn{4}{|c|}{ Kolmogorov-Smirnov ${ }^{\mathrm{a}}$} & \multicolumn{3}{c|}{ Shapiro-Wilk } \\
\cline { 2 - 8 } & Statistic & \multicolumn{1}{c|}{$\mathrm{df}$} & \multicolumn{1}{c|}{ Sig. } & Statistic & \multicolumn{1}{c|}{ df } & \multicolumn{1}{c|}{ Sig. } \\
\hline Unstandardized Residual &, 082 & 58 &, $200^{*}$ &, 970 & 58 &, 168 \\
\hline
\end{tabular}

a. Lilliefors Significance Correction

${ }^{*}$. This is a lower bound of the true significance.

\begin{tabular}{|l|c|r|r|r|r|}
\hline \multicolumn{1}{|c|}{ Model Summary } \\
\hline 1 & $R$ & $R$ Square & $\begin{array}{c}\text { Adjusted R } \\
\text { Square }\end{array}$ & $\begin{array}{c}\text { Std. Error of } \\
\text { the Estimate }\end{array}$ & Durbin-Watson \\
\hline 1 &, $415^{\mathrm{a}}$ &, 172 &, 075 &, 07475 & 2,089 \\
\hline
\end{tabular}

a. Predictors: (Constant), CFO, Lev, AUDxUmur_Bfore, Size, Umur_Bfore_IPO, AUD

b. Dependent Variabel: Tgkt_Bunga 


\begin{tabular}{|c|c|c|c|c|c|c|c|}
\hline \multirow{2}{*}{\multicolumn{2}{|c|}{ Model }} & \multicolumn{2}{|c|}{ Unstandardized Coefficients } & \multirow[b]{2}{*}{$\mathrm{t}$} & \multirow[b]{2}{*}{ Sig. } & \multicolumn{2}{|c|}{ Collinearity Statistics } \\
\hline & & B & Std. Error & & & Tolerance & VIF \\
\hline \multirow[t]{7}{*}{1} & (Constant) & 008 & 109 & ,074 & 942 & & \\
\hline & Umur_Bfore_IPO & 000 & 004 & 066 & 948 & ,523 & 1,912 \\
\hline & AUD &,- 079 & 045 & $-1,764$ & 084 & ,209 & 4,786 \\
\hline & AUDxUmur_Bfore & 013 & 006 & 2,223 & 031 & 220 & 4,542 \\
\hline & Lev &, 001 & ,006 & ,083 & ,934 & ,855 & 1,170 \\
\hline & Size & 009 & 009 & ,998 & ,323 & ,869 & 1,150 \\
\hline & CFO &,- 059 & ,050 & $-1,174$ & ,246 & ,841 & 1,190 \\
\hline
\end{tabular}

LAMPIRAN 3. ASUMSI KLASIK (HIPOTESIS DUA / SAMPEL PRIVAT

PANJANG)

Tests of Normality

\begin{tabular}{|c|c|c|c|c|c|c|}
\hline & \multicolumn{3}{|c|}{ Kolmogorov-Smirnova } & \multicolumn{3}{|c|}{ Shapiro-Wilk } \\
\hline & Statistic & $\mathrm{df}$ & Sig. & Statistic & $\mathrm{df}$ & Sig. \\
\hline Unstandardized Residual & ,067 & 71 & ,200* & ,968 & 71 & ,066 \\
\hline
\end{tabular}

a. Lilliefors Significance Correction

*. This is a lower bound of the true significance.

Model Summaryb

\begin{tabular}{|l|r|r|r|r|r|}
\hline Model & \multicolumn{1}{|c|}{$\mathrm{R}$} & R Square & \multicolumn{1}{c|}{$\begin{array}{c}\text { Adjusted R } \\
\text { Square }\end{array}$} & $\begin{array}{c}\text { Std. Error of } \\
\text { the Estimate }\end{array}$ & \multicolumn{1}{c|}{$\begin{array}{c}\text { Durbin- } \\
\text { Watson }\end{array}$} \\
\hline 1 &, $261^{\mathrm{a}}$ &, 068 &,- 004 &, 05763 & 1,798 \\
\hline
\end{tabular}

a. Predictors: (Constant), CFO, Umur_Bfore_IPO, Lev, Size, AUDxUmur_Bfore

b. Dependent Variabel: Tgkt_Bunga

\begin{tabular}{|c|c|c|c|c|c|c|c|}
\hline \multirow{2}{*}{\multicolumn{2}{|c|}{ Model }} & \multicolumn{2}{|c|}{ Unstandardized Coefficients } & \multirow[b]{2}{*}{$\mathrm{t}$} & \multirow[b]{2}{*}{ Sig. } & \multicolumn{2}{|c|}{ Collinearity Statistics } \\
\hline & & $\mathrm{B}$ & Std. Error & & & Tolerance & VIF \\
\hline \multirow[t]{6}{*}{1} & (Constant) & ,181 & ,082 & 2,216 & ,030 & & \\
\hline & Umur_Bfore_IPO & $2,380 \mathrm{E}-5$ & 001 & ,026 & ,980 & ,703 & 1,422 \\
\hline & AUDxUmur_Bfore & $4,894 \mathrm{E}-5$ & 001 & ,089 & ,930 & 665 & 1,505 \\
\hline & Lev & ,003 & ,003 & 1,069 & ,289 & ,762 & 1,312 \\
\hline & Size &,- 007 & 007 &,- 996 & 323 & ,767 & 1,304 \\
\hline & CFO & ,012 & 009, & 1,404 & 165, & 896 & 1,116 \\
\hline
\end{tabular}

